\title{
Electronic Health Record Patient Portal Adoption by Health Care Consumers: An Acceptance Model and Survey
}

Jorge Tavares*, MSc; Tiago Oliveira*, PhD

NOVA Information Management School (IMS), Universidade Nova de Lisboa, Lisboa, Portugal

*all authors contributed equally

\section{Corresponding Author:}

Jorge Tavares, MSc

NOVA Information Management School (IMS)

Universidade Nova de Lisboa

Campus de Campolide

Lisboa, 1070-312

Portugal

Phone: 351917330943

Fax: 351213828611

Email: d2012072@novaims.unl.pt

\section{Abstract}

Background: The future of health care delivery is becoming more citizen centered, as today's user is more active, better informed, and more demanding. Worldwide governments are promoting online health services, such as electronic health record (EHR) patient portals and, as a result, the deployment and use of these services. Overall, this makes the adoption of patient-accessible EHR portals an important field to study and understand.

Objective: The aim of this study is to understand the factors that drive individuals to adopt EHR portals.

Methods: We applied a new adoption model using, as a starting point, Ventkatesh's Unified Theory of Acceptance and Use of Technology in a consumer context (UTAUT2) by integrating a new construct specific to health care, a new moderator, and new relationships. To test the research model, we used the partial least squares (PLS) causal modelling approach. An online questionnaire was administrated. We collected 360 valid responses.

Results: The statistically significant drivers of behavioral intention are performance expectancy (beta $=.200 ; t=3.619$ ), effort expectancy (beta=.185; $t=2.907$ ), habit (beta $=.388 ; t=7.320$ ), and self-perception (beta $=.098 ; t=2.285$ ). The predictors of use behavior are habit (beta $=0.206 ; t=2.752$ ) and behavioral intention (beta $=0.258 ; t=4.036$ ). The model explained $49.7 \%$ of the variance in behavioral intention and $26.8 \%$ of the variance in use behavior.

Conclusions: Our research helps to understand the desired technology characteristics of EHR portals. By testing an information technology acceptance model, we are able to determine what is more valued by patients when it comes to deciding whether to adopt EHR portals or not. The inclusion of specific constructs and relationships related to the health care consumer area also had a significant impact on understanding the adoption of EHR portals.

(J Med Internet Res 2016;18(3):e49) doi: 10.2196/jmir.5069

\section{KEYWORDS}

UTAUT2; technology adoption; eHealth; health care consumers; electronic health records; technology acceptance

\section{Introduction}

\section{Overview}

Our study focuses on a specific type of eHealth technology, the patient-accessible electronic health record (EHR) portals [1-5]. To better understand the definition of EHR portals it is important to have a clear view of the technologies that support them. First are the patient portals, health care-related online applications that allow patients to interact and communicate with their health care providers $[3,5]$. The second is the EHR, meaning a repository of patient data in digital form, stored and exchanged securely. EHR systems are the software platforms that physician offices and hospitals use to create, store, update, and maintain EHRs for patients [2]. By definition, an EHR portal is a Web-based application that combines an EHR system and a patient portal, not only for patients to interact with their health 
care providers, but also to access their own medical records and medical exam results [2-7].

EHR portals may help patients carry out self-management activities, thereby making the use of the health care system more effective and sustainable, not only from the patient care standpoint, but also from a financial perspective due to rising health care costs and budgets in many countries [8-11]. A recent survey of US health care providers shows that $57 \%$ of health care institutions already have a portal in place and $71 \%$ value the integration of the EHR system within the patient portal by choosing a product (ie, patient portal interface) from their EHR vendor [7]. In Europe, not only health care providers, such as hospitals and clinics, provide EHR portals, but also governmental institutions make these platforms available to patients $[8,12]$.

This concept of a national-level patient portal progressed into a trans-European initiative, the European Patients Smart Open Services (epSOS). epSOS concentrates on developing a practical eHealth framework, and an information and communication technology (ICT) infrastructure that enables secure access to patient health information among different European health care systems [13]. The pilot stage of this project, which ended in June 2014, focused on cross-border eHealth services in the following areas: patient summary and cross-border use of electronic prescriptions [13]. In the United States, a new guidance was issued by the Centers for Medicare \& Medicaid Services (CMS) called Stage 2 meaningful use [5,14]. This guidance requires that the eligible professionals and hospitals that participate in the Medicare \& Medicaid EHR Incentive Programs must give their patients secure online access to their health information, including EHRs [5,7,14]. Stage 2 meaningful use boosted the development of new integrated EHR portals in the United States by health care providers that, according to the new guidance, must not only implement it but also demonstrate effective use by the patients $[5,7,14]$. According to the literature, the most used features in EHR patient portals are as follows: scheduling medical appointments, email messaging, requesting prescription refills, and checking of patients' medical exams $[1,3,15]$.

The aim of this study is to identify a set of determinants in the adoption of electronic health record portals by health care consumers. In our study, we examine these determinants in the field of eHealth technology use and acceptance by health care consumers. We then propose a new research model based on Venkatesh's Unified Theory of Acceptance and Use of Technology in a consumer context (UTAUT2) by integrating a new construct from the health care area, self-perception (SP), and a new moderator, chronic disability (CD) [2,16-18].

In this paper, we first review the literature concerning information technology (IT) adoption models regarding consumer health care. We then present a research model to analyze EHR portals for the health care consumer. Finally, we discuss the issue and present conclusions.

\section{Theoretical Background}

There have been several theoretical models developed from theories in psychology, sociology, and consumer behavior employed to explain technology acceptance and use [18]. The goal of this study is to focus specifically on EHR portal adoption from the perspective of the health care consumer, so it is of the utmost importance to review the literature in this particular field. Adoption of eHealth technologies by patients is clearly a very important topic in information systems (IS) in health care. The adoption of eHealth technologies by health care consumers still requires more attention and research due to the limited number of studies reported in the literature to date [2,19-22]. The use of the UTAUT2 model might be beneficial to eHealth adoption due to its consumer-specific constructs like price value [21].

When studying eHealth and health care adoption by health care professionals, the most common adoption models used are the technology acceptance model (TAM) [23,24] and the unified theory of acceptance and use of technology (UTAUT) [25-29]. Evaluating the studies published in the field of consumer health IT adoption, and more specifically in the use and adoption of eHealth tools by the health care consumer, most studies use TAM or extensions of TAM [19,30-34]. TAM was designed and tailored in IS contexts to predict information technology acceptance and usage on the job. TAM uses three dimensions: perceived usefulness (PU), that is "the degree to which a person believes that using a particular system would enhance his or her job"; perceived ease of use (PEOU), that is "the degree to which a person believes that using a particular system would be free of effort"; and attitude toward technology use [32,35,36]. PU and PEOU together affect the attitude toward technology use, which in turn influences behavioral intention to adopt $[32,36]$. UTAUT formulates a unified model that integrates elements of eight models in the field of IT acceptance, including from TAM, which incorporates the concept of PU as performance expectancy and PEOU as effort expectancy [35]. Apart from these two constructs from TAM, UTAUT also uses two other constructs, social influence and facilitating conditions (FC). All of these are joined together in the model along with four moderators-age, gender, experience, and voluntariness of use. The model and its relationships are illustrated in Figure 1 [35]. The $R^{2}$ obtained with UTAUT was superior to those of any of the individual models, including TAM, making a synthesis of the different theories by bringing together into the model the constructs that have a significant impact $[18,35]$. For example, with UTAUT it is possible to measure the impact of social influence on behavioral intention, something that was not measured with TAM $[18,35]$. Although UTAUT provides better results than TAM and other IS adoption models, the focus of UTAUT is also the employee technology acceptance at the individual level, which is not the focus of our paper because our target group is health care consumers [18].

Ideally, we need a model tailored to the consumer use context, and in this specific field, UTAUT2 was developed with this goal, obtaining very good results $[18,21]$. This new model includes the same four UTAUT constructs, but which are moderated differently. The constructs are now moderated only by age, gender, and experience [18]. The moderator voluntariness of use was dropped since the target population was not obliged to use the technology [18]. UTAUT2 also introduces three new constructs (ie, specific consumer adoption constructs): hedonic motivation, price value, and habit. Hedonic 
motivation and price value explain behavioral intention, while habit explains behavioral intention and use behavior [18]. Compared to UTAUT, the extensions proposed in UTAUT2 that are consumer specific produced a substantial improvement in the variance explained in behavioral intention (from $56 \%$ to $74 \%$ ) and technology use (from $40 \%$ to $52 \%$ ) [18]. Including these three new constructs made UTAUT2 a more suitable model for consumer-centered technologies [18]. Figure 2 explains the UTAUT2 model. The definitions of the different constructs used in the UTAUT and UTAUT2 models are provided in the Research Model section of this paper. Most of the existing UTAUT2 literature focuses on other types of technologies, such as online purchasing, mobile banking, and
Web-based services [18,37-39]. A recently published study used UTAUT2 in health and fitness apps, which is not exactly the same technology scope and type of eHealth service as EHR portals, but obtained the following results: performance expectancy, hedonic motivation, price value, and habit were significant predictors of intention of continued usage [40].

Table 1 summarizes some of the studies performed in the area of eHealth, the theory or theories behind the studies, the dependent variable that is being explained by each study, and the most important findings. The target population in all studies was patients and the technologies have similarities with EHR portals $[2,16,30,31,41,42]$.

Figure 1. Unified Theory of Acceptance and use of Technology (UTAUT) model adapted from Venkatesh et al [35]. Notes: 1. Moderated by age and gender; 2. Moderated by age, gender, and experience; 3 . Moderated by age and experience; 4 . Moderated by age, gender, experience, and voluntariness of use.

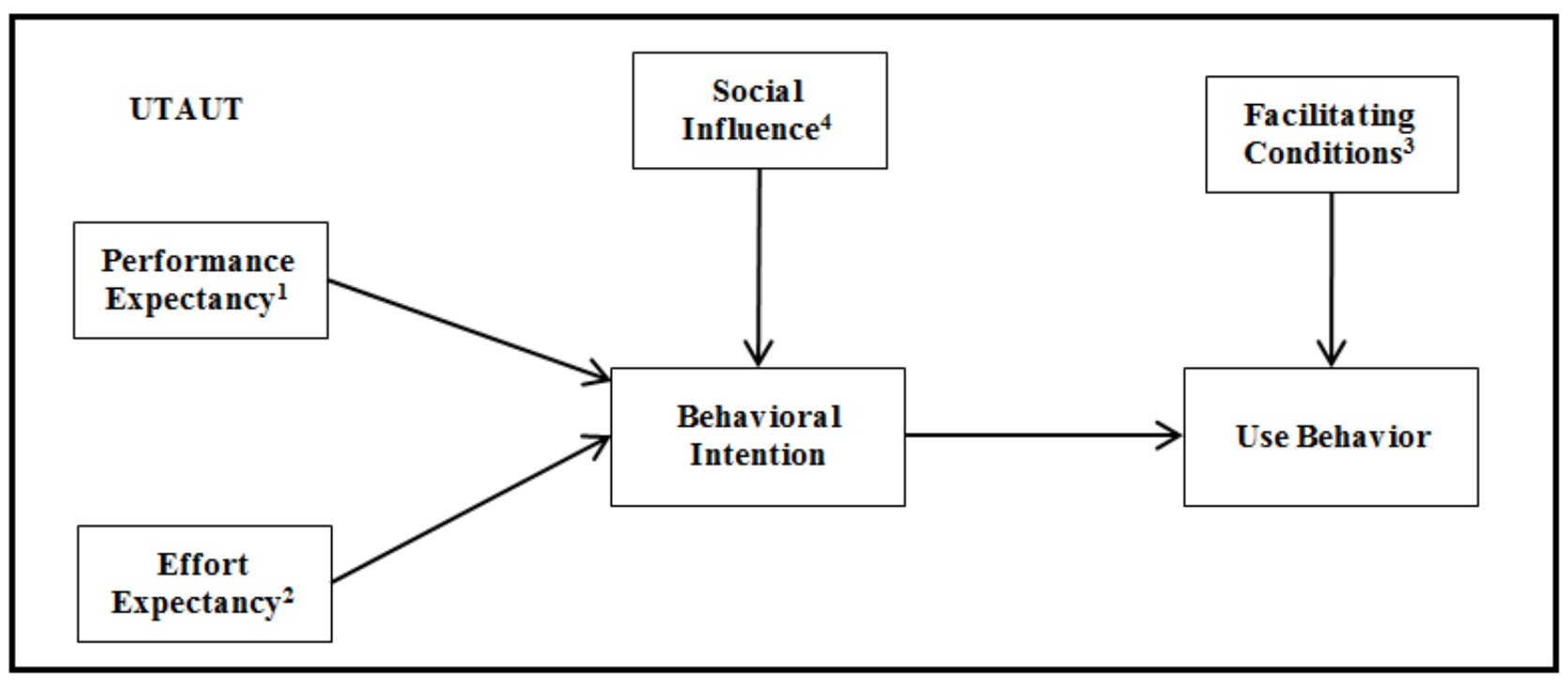


Figure 2. Unified Theory of Acceptance and use of Technology in a consumer context (UTAUT2) model adapted from Venkatesh et al [18]. Notes: 1. Moderated by age and gender; 2. Moderated by age, gender, and experience; 3 . Effect on behavioral intention is moderated by age, gender, and experience. Effect on use behavior is moderated by age and experience; 4 . Moderated by experience.

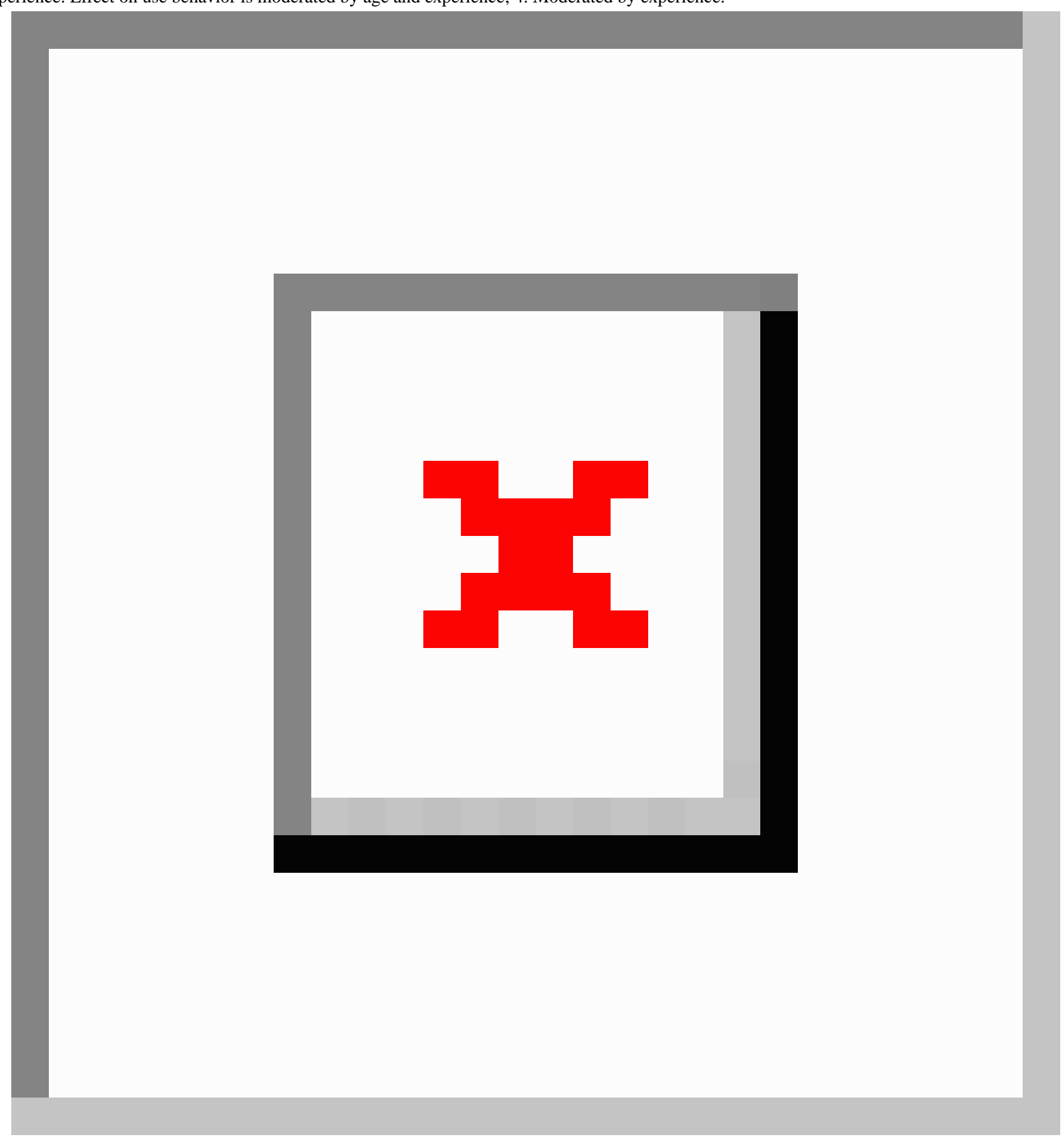


Table 1. eHealth adoption models.

\begin{tabular}{|c|c|c|c|}
\hline Theory & Dependent variable & Findings & Reference \\
\hline $\begin{array}{l}\text { TAM }{ }^{\mathrm{a}}, \text { motivational model } \\
(\mathrm{MM}), \text { integrated model (IM) }\end{array}$ & $\begin{array}{l}\text { eHealth behavioral } \\
\text { intention }\end{array}$ & $\begin{array}{l}\text { Users' perceived ease of use (PEOU), users' perceived technology usefulness } \\
(\mathrm{PU}) \text {, intrinsic motivation (IM), and extrinsic motivation (MM) have a signif- } \\
\text { icant positive influence on behavioral Intention. } \\
\text { IM does not have a better performance than TAM or MM when predicting } \\
\text { behavioral Intention. }\end{array}$ & {$[30]$} \\
\hline $\begin{array}{l}\text { Elaboration likelihood model } \\
\text { (ELM), concern for information } \\
\text { privacy (CFIP) }\end{array}$ & $\begin{array}{l}\mathrm{EHR}^{\mathrm{b}} \text { behavioral in- } \\
\text { tention }\end{array}$ & $\begin{array}{l}\text { Positively framed arguments and issue involvement generate more favorable } \\
\text { attitudes toward EHR behavioral intention. } \\
\text { CFIP is negatively associated with likelihood of adoption. }\end{array}$ & {$[2]$} \\
\hline TAM (qualitative study) & $\begin{array}{l}\text { eHealth services be- } \\
\text { havioral Intention }\end{array}$ & $\begin{array}{l}\text { PU seemed to be important. } \\
\text { PEOU did not seem to be an issue. } \\
\text { Although experience is not a TAM construct, it seemed to have influenced } \\
\text { behavioral Intention. }\end{array}$ & {$[41]$} \\
\hline Personal empowerment & $\begin{array}{l}\text { Internet use behavior } \\
\text { as a source of infor- } \\
\text { mation }\end{array}$ & $\begin{array}{l}\text { There are three types of attitudes encouraging Internet use to seek health in- } \\
\text { formation: professional, consumer, and community logic. }\end{array}$ & [16] \\
\hline $\begin{array}{l}\text { Extended TAM in health infor- } \\
\text { mation technology (HIT) }\end{array}$ & $\begin{array}{l}\text { HIT behavioral inten- } \\
\text { tion }\end{array}$ & $\begin{array}{l}\text { PU, PEOU, and perceived threat significantly impacted health consumers' } \\
\text { behavioral intention. }\end{array}$ & {$[31]$} \\
\hline
\end{tabular}

TAM: technology acceptance model.

${ }^{\mathrm{b}} \mathrm{EHR}$ : electronic health record.

\section{Research Model}

UTAUT2 was developed as an adoption model providing the general factors of IT adoption in consumer use. However, according to Venkatesh et al [18], in certain situations in which the technology may be influenced by specific factors it may be necessary to extend the model with new constructs, moderators, and relationships. We therefore identified key additional constructs and relationships based on the literature review that are specific to IT health care adoption to be integrated into UTAUT2, thus tailoring it to the eHealth consumer context, with the special aim of studying the adoption of EHR portals. We did this by (1) identifying a key construct from earlier research in health care-self-perception - and by (2) adding a new moderator specific to health care use-chronic disability.

Published studies suggest that patients with chronic illness, severe illness, or disability are more likely to use eHealth technologies if they have the resources and support available $[17,43,44]$. A national survey in the United States shows that $86 \%$ of people living with disability or chronic illness with Internet access have looked online for information about health topics, compared with $79 \%$ of Internet users with no chronic conditions [44]. A recent study using a TAM extended version with the health belief model (HBM) measured the perceived health risk to chronic diseases [32]. Using chronic disability with UTAUT2 in the field of EHR portals is not only a new approach, but also one that takes advantage of the existence of the construct facilitating conditions-defined as the individual perception of the support available for using a technology activity [35] - that can be moderated by chronic disability, something that can be more properly tested with UTAUT2 than with TAM [18]. Recent studies tackled the need to study the variables that can drive the patients to be more active in their own health management $[8,21]$. Self-perception in health [45-47], called the self-perception construct, considers that the perceived, rather than the real, severity of the health complaint could be the propelling force behind the action in health care $[45,47,48]$. EHR portals are interfaces that links patients with health care professionals, and this construct is relevant to understanding if the patient's awareness about her/his own health status can be a driver to adopt EHR portals. Other studies using the health belief model with TAM [31,32] incorporated other constructs related to the health belief model concept. One such study was by Kim and Park [31], who studied health-related constructs like health belief and concerns or perceived health status, conceptually similar to self-perception, that have been shown to have an indirect effect on the behavioral intention to use health information technology [31]. This shows the importance of measuring this dimension in our study with a consumer-centered adoption model. Figure 3 illustrates the new research model. 
Figure 3. The research model. Notes: 1 . Moderated by age or gender; 2. Moderated by age; 3 . Moderated by chronic disability on use.

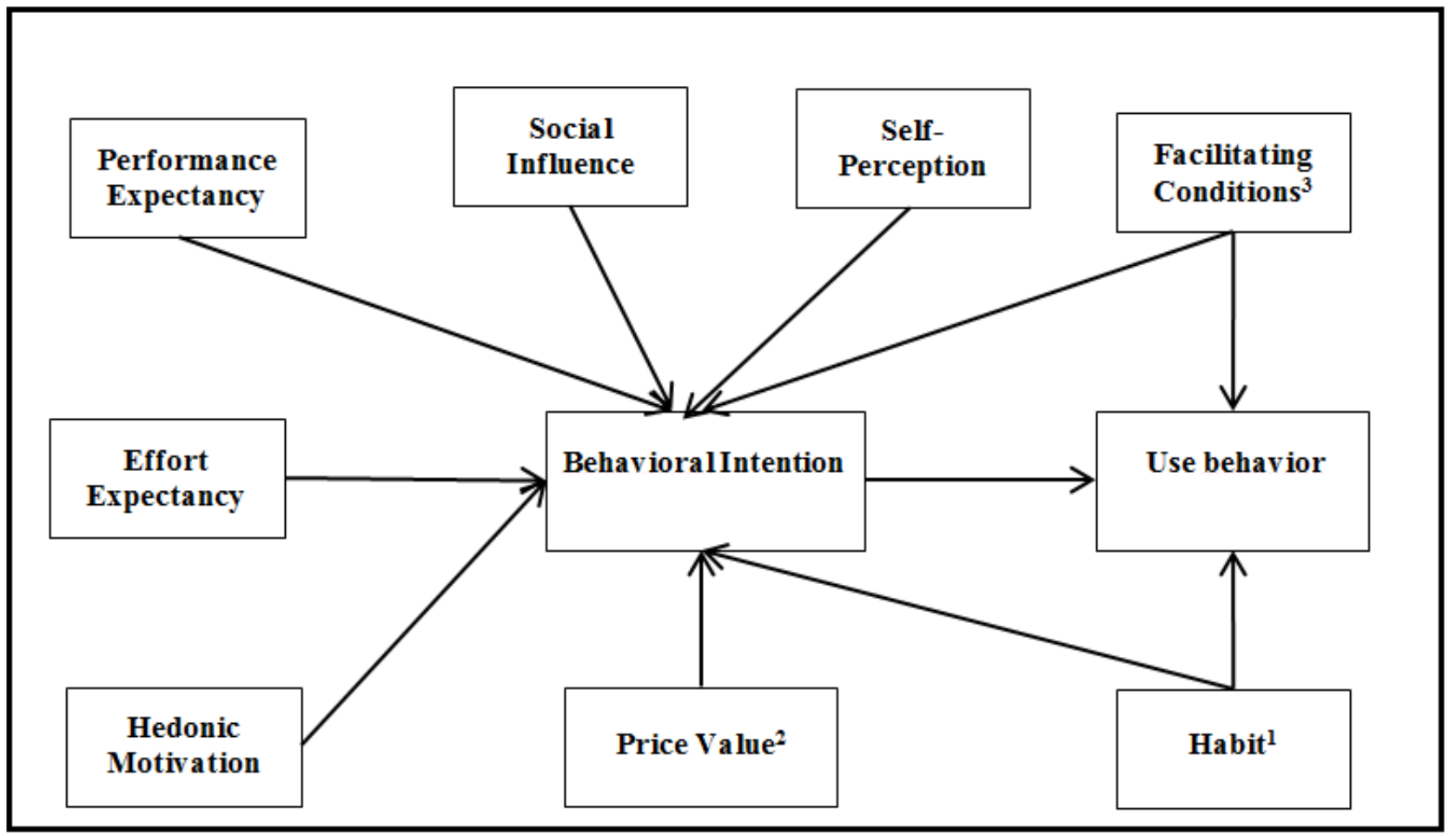

\section{Research Model: Extended Unified Theory of Acceptance and Use of Technology in a Consumer Context Model}

Performance expectancy is defined as the degree to which using a technology will provide benefits to consumers in carrying out certain activities [35,49]. Our literature review indicates that health care consumers tend more to adopt eHealth technologies that provide clear benefits, such as obtaining an electronic medical prescription via EHR portals [8,50,51]. Hypothesis 1 (H1) states that performance expectancy will positively influence behavioral intention.

Effort expectancy is the degree of ease related to consumers' use of technology [35]. The easier it is for consumers to understand and use an eHealth technology, the greater is the probability that they will adopt it [8,51]. Hypothesis $2(\mathrm{H} 2)$ states that effort expectancy will positively influence behavioral intention.

Social influence is the extent to which consumers perceive that others who are important to them (eg, friends and family) believe they should use a particular technology [18]. In the case of eHealth, this can also be an important construct since people who share the same diseases (eg, multiple sclerosis) or the same health condition (eg, obesity) tend to be influenced by others having the same condition [20,52]. Hypothesis 3 (H3) states that social influence will positively influence behavioral intention.

The construct, facilitating conditions, is defined as the individual perception of the support available for using a technology activity [35]. One of the barriers to consumers' use of health services over the Internet is the consumers' lack of resources to access these platforms [51], suggesting that users with better conditions to use eHealth technologies favor EHR portals adoption. Hypothesis 4 (a) (H4 [a]) states that facilitating conditions will positively influence behavioral intention.

Chronic disability is an incapacitating situation (eg, chronic illness) that affects a patient permanently or for long-term periods. Our literature review reveals that patients with chronic illness or disability are more likely to use eHealth technologies if they have the resources and support available (ie, facilitating conditions) $[17,20]$. Hypothesis $4(b)(\mathrm{H} 4[\mathrm{~b}])$ states that chronic disability will moderate the effect of facilitating conditions on use behavior, such that the effect will be stronger for chronically disabled people.

Hedonic motivation is defined as intrinsic motivation (eg, enjoyment) and has been included as a key predictor in much of the reported consumer behavior research [18]. Obtaining and dealing with information about our health status by using eHealth technologies may be an enjoyable process, or in some cases may not be when a patient has, for example, an incurable disease [53]. Nevertheless, in a recent study with UTAUT2 in eHealth, hedonic motivation was found to have a significant impact on behavioral intention [40]. We then propose that this specific construct may have a significant impact in predicting EHR portal use. Hypothesis 5 (H5) states that hedonic motivation will have a positive influence on behavioral intention.

Price value in a consumer use environment is also a relevant factor as, unlike workplace technologies, consumers must bear the costs related with the purchase of devices and services [18]. If a patient can obtain her/his medical prescription via an EHR portal, she/he can save transportation costs by avoiding a trip to a health center or hospital. The better the perception a health care consumer has about the price value of an eHealth technology (ie, that it can help save money), the more likely it 
is that she/he will adopt it [8,11]; older people tend to give more importance to price in eHealth [21]. Hypothesis 6 (H6) states that age will moderate the effect of price value on behavioral intention, such that the effect will be stronger for older people.

Habit can be defined as the extent to which people tend to execute behaviors automatically because of learning [18]. We can expect that habit will positively influence eHealth adoption, as it does in other IT adoption fields, since habit is a concept that should not be specific to an IT technology [18]. The literature review indicates that in eHealth, younger people and women tend to have the habit to use more eHealth technologies [17,20]. Hypothesis 7 (al) (H7 [a1]) states that age will moderate the effect of habit on behavioral intention, such that the effect will be stronger for younger people. Hypothesis 7 (a2) (H7 [a2]) states that gender will moderate the effect of habit on behavioral intention, such that the effect will be stronger for women. Hypothesis 7 (bl) (H7 [b1]) states that age will moderate the effect of habit on use behavior, such that the effect will be stronger for younger people. Hypothesis 7 (b2) (H7 [b2]) states that gender will moderate the effect of habit on use behavior, such that the effect will be stronger for women.

Behind the concept, self-perception, is the health belief model. The model assumes that subjective health considerations determine whether people perform a health-related action, such as consulting their physician [45]. For example, the health belief model considers the perceived, rather than the real, severity of the complaint to be the propelling force behind the action [45].

Studies about patients that look for information online seem to confirm the concept of the health belief model; the results show that a larger proportion of respondents who described their health as poor indicated that they looked for health-related information online "often" compared with those who described their health as fair or better [54]. We therefore add self-perception as a predictor of health consumer behavioral intention to use a technology. Hypothesis $8(\mathrm{H} 8)$ states that self-perception will positively influence behavioral intention.

The role of intention as a predictor of usage is critical and has been well established not only in IS in general, but also in health care and eHealth, with the literature suggesting that the driver of using specific eHealth platforms is preceded by the intention to use them [18,22,30,31,35,45]. Hypothesis 9 (H9) states that behavioral Intention will positively influence use behavior.

\section{Methods}

\section{Measurement}

All of the items were adopted from Venkatesh et al [18], Wilson and Lankton [30], and Vandekar et al [45] with small modifications in order to adjust to EHR portal technology. The items are shown in Multimedia Appendix 1. The questionnaire was administered in Portuguese through a Web hosting service after being translated by a professional translator. In order to ensure that the content did not lose its original meaning, a back-translation was made from the Portuguese instrument to English, again by a professional translator, and compared to the original [55].
The scales' items were measured on a 7-point Likert scale, ranging from strongly disagree (1) to strongly agree (7). Use was measured on a different scale. The scale from UTAUT2-from never to many times per day-was adapted to never to every time I need, since EHR portal usage is not as regular as mobile Internet usage. Demographic questions about age and gender were also included; age was measured in years and gender was coded as a dummy variable ( 0 or 1$)$, with women represented by 0 . Chronic disability was coded as a dummy variable ( 0 or 1$)$, with its absence represented by 0 .

Before the respondents could see any of the questions, an introduction was made explaining the concept of EHR portals (see Multimedia Appendix 1). The aim of this introduction was to ensure that respondents were aware of this concept and had prior knowledge and contact with EHR portals, because the absence of this prior knowledge is an exclusion criterion.

\section{Data Collection}

A pilot survey was conducted to validate the questions and the scale of the survey. From the pilot survey, we had 30 responses demonstrating that all of the items were reliable and valid. The data from the pilot survey were not included in the main survey.

According to the literature, the technology that we are studying (EHR portals) is being used by less than $7 \%$ of the total number of health care consumers or patients $[5,7,56]$. We are therefore sampling a group of people that could be defined as a rare population, as it constitutes a small proportion of the total population, and specific sample strategies can be used that are suitable in this case [57,58]. We have a disproportionate stratification of our target population compared with the general population, because according to the literature, users and early adopters of these types of platforms have significantly higher education $[19,43,59]$. As a result, we focused our sampling strategy in places where our target population-users of EHR portals-are more concentrated [57,58]; thus, we selected educational institutions.

The survey, via hyperlink, was sent by email in October 2013 to a total of 1618 people at three institutions that provide educational services, from which we obtained 350 responses. NOVA Information Management School (IMS) approved and verified the ethical compliance of the questionnaire before its use. All participants were informed by email about the study purpose, confidentiality protection, and the anonymity of the information collected. A reminder was sent 2 weeks after the first email, only to those who had not responded to the first email, in order to improve the response rate. Following the reminder, we had a total of 465 respondents out of 1618 (28.74\% response rate). After removing the invalid responses, the final sample consisted of 360 respondents. A questionnaire was considered invalid if not all questions were answered. According to our statistical modelling method, we cannot use incomplete questionnaires [60,61].

\section{Data Analysis}

To test the research model, we used the partial least squares (PLS) method, which is a causal modelling approach that represents a variance-based technique of path modelling [60]. Our main reasons for choosing this method were the complexity 
of the model (ie, many moderators) and the fact that the PLS method is oriented to explain variance of the research model and to identify key constructs [60-62]. We used the software program SmartPLS version 2.0.M3 (SmartPLS GmbH) [63] to estimate the PLS. Before testing the structural model, we examined the measurement model to assess construct reliability, indicator reliability, convergent validity, and discriminant validity.

\section{Results}

\section{Sample Characteristics}

Our sample characteristics are shown in Table 2.

The literature mentions that users of EHR portals are younger than the population average and have significantly higher education $[19,43,59]$; the results shown in Table 2 are aligned with the literature findings.

\section{Usage Results}

Use was measured on a scale that ranges from never (1) to every time I need (7). In Figure 4, we grouped the results by nonfrequent users of a particular EHR portal feature (scale from 1 to 2 ), medium users (scale from 3 to 5), and high users (scale from 6 to 7). These results show that the fact that people know about the technology and enter and register in these portals does not make them frequent users. Our study results are aligned with those of earlier studies and reports $[3,12,17]$; also, the results from our study show that only $30 \%$ of users use a portal regularly to check their EHR. Medical appointment scheduling is the feature with the highest usage.

Table 2. Sample characteristics $(n=360)$.

\begin{tabular}{lll}
\hline Variable and category & & Frequency, $\mathrm{n}(\%)$ \\
\hline Age in years & $18-20$ & $69(19.2)$ \\
& $21-24$ & $75(20.8)$ \\
& $25-30$ & $76(21.1)$ \\
& $31-40$ & $89(24.7)$ \\
Gender & $>40$ & $51(14.2)$ \\
Chronic illness/disability & Male & $142(39.4)$ \\
& Female & $218(60.6)$ \\
Education & No & $308(85.6)$ \\
& Yes & $52(14.4)$ \\
& Undergraduate & $132(36.7)$ \\
& Bachelor's degree & $87(24.2)$ \\
& Postgraduate & $70(19.4)$ \\
& Master's degree or more & $71(19.7)$ \\
\hline
\end{tabular}


Figure 4. Types of usage patterns of electronic health record (EHR) portals. UB: use behavior; UB1: management of personal information and communication with health providers; UB2: medical appointment schedule; UB3: check their own EHR; UB4: request for medical prescription renewals.

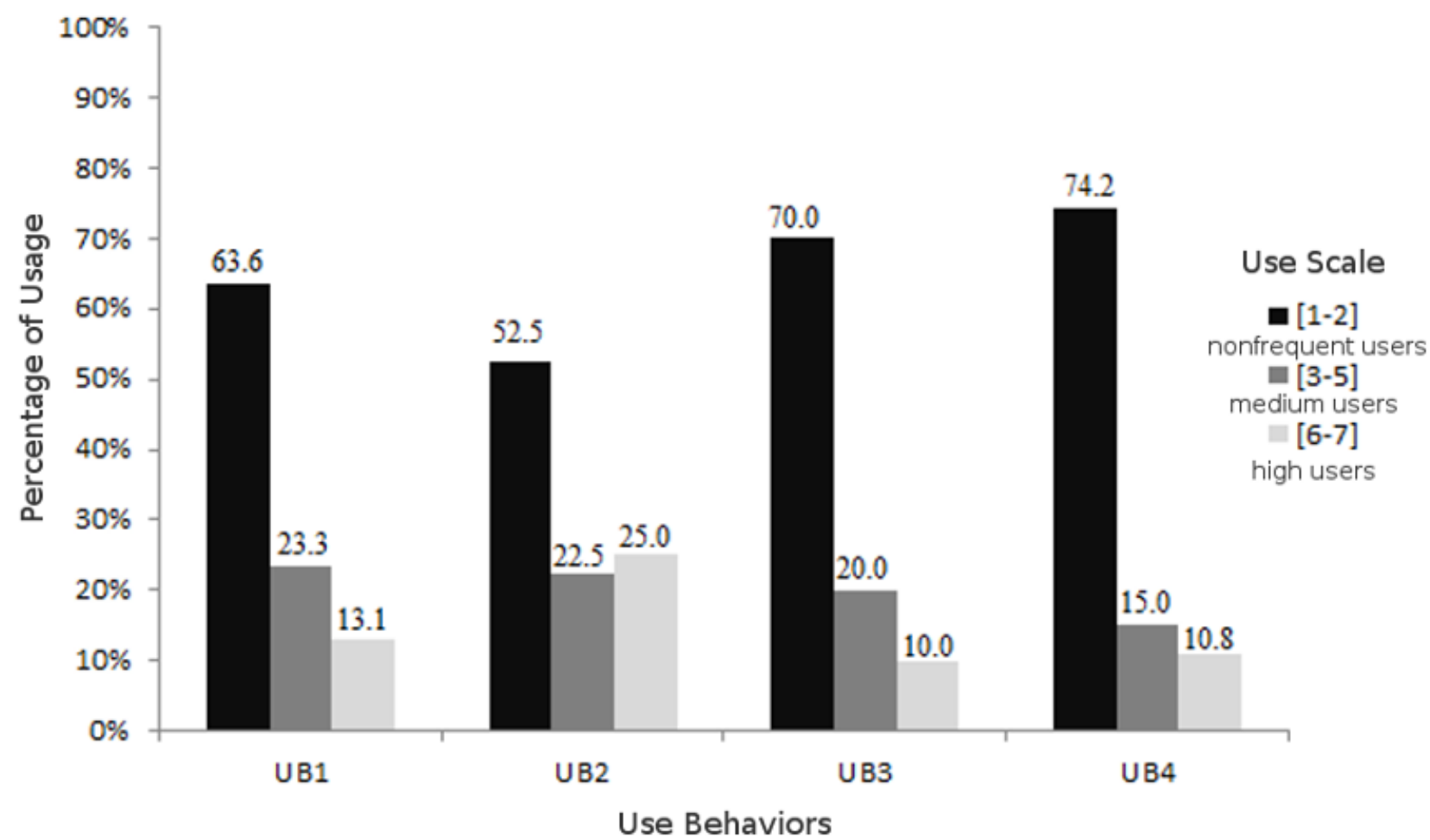

\section{Measurement Model}

The results of the measurement model are shown in Tables 3, 4, and 5 and in Multimedia Appendix 2. To evaluate construct reliability, one can use Cronbach alpha or the composite reliability coefficient (CR). Although Cronbach alpha is more often used, CR is more appropriate for PLS since it prioritizes indicators according to their individual reliability and takes into account that indicators have different loadings, unlike Cronbach alpha [64]. Table 3 reports that all constructs have a CR greater than .70 , showing evidence of internal consistency $[60,65]$.

Table 3. Cronbach alpha, composite reliability, and average variance extracted.

\begin{tabular}{llll}
\hline Construct & Cronbach alpha & $\begin{array}{l}\text { Composite reliability coefficient } \\
\text { (CR) }\end{array}$ & $\begin{array}{l}\text { Average variance extracted } \\
\text { (AVE) }\end{array}$ \\
\hline Performance expectancy & .90 & .94 & .83 \\
Effort expectancy & .91 & .94 & .79 \\
Social influence & .98 & .98 & .96 \\
Facilitating conditions & .80 & .87 & .63 \\
Hedonic motivation & .93 & .96 & .88 \\
Price value & .93 & .96 & .88 \\
Habit & .74 & .85 & .66 \\
Self-perception & .67 & .81 & .52 \\
Behavior intention & .90 & .94 & .83 \\
\hline
\end{tabular}

In order to have good indicator reliability, it is desired that the latent variable explain more than half of the indicators' variances. The correlation between the constructs and their indicators should ideally be greater than $.70(\sqrt{ } .50 \approx .70)[60,65]$. However, an item is recommended to be eliminated only if its outer standardized loadings are lower than .40 [66]. The measurement model has issues with two indicators' reliabilities-SP3 and SP5-which were removed; FC4, SP4, and SP6 are lower than .70, but still greater than .40 (see Multimedia Appendix 2).
In order to assess the convergent validity, we used average variance extracted (AVE). The AVE should be greater than .50, so that the latent variable explains, on average, more than $50 \%$ of its own indicators [64,67]. As shown in Table 3, all of the indicators respect this criterion. Finally, discriminant validity can be evaluated with the Fornell-Larcker criterion [67]. This criterion claims that a latent variable shares more variance with its indicators than with the other latent variables, so that the square root of AVEs should be greater than the correlations between the construct [60,67]. As seen in Table 4, all 
diagonal — square root of AVEs — are greater than the correlation between constructs-off-diagonal elements. In addition, another criterion can be assessed, although it is a more liberal one [60].
For each construct, we also examined if loadings are greater than all of its cross-loadings $[61,68]$. This criterion is also met, as seen in Multimedia Appendix 2.

Table 4. Correlations ${ }^{\mathrm{a}}$ and square root of average variance extracted ${ }^{\mathrm{b}}$.

\begin{tabular}{|c|c|c|c|c|c|c|c|c|c|c|c|c|c|}
\hline & $\mathrm{PE}^{\mathrm{c}}$ & $\mathrm{EE}^{\mathrm{d}}$ & $\mathrm{SI}^{\mathrm{e}}$ & $\mathrm{FC}^{\mathrm{f}}$ & $\mathrm{HM}^{\mathrm{g}}$ & $\mathrm{PV}^{\mathrm{h}}$ & $\mathrm{HT}^{\mathrm{i}}$ & $\mathrm{SP}^{\mathrm{j}}$ & $\mathrm{BI}^{\mathrm{k}}$ & $\mathrm{UB}^{1}$ & Age & Gender & $\mathrm{CD}^{\mathrm{m}}$ \\
\hline $\mathrm{PE}$ & .91 & & & & & & & & & & & & \\
\hline $\mathrm{EE}$ & .47 & .89 & & & & & & & & & & & \\
\hline SI & .31 & .24 & .98 & & & & & & & & & & \\
\hline FC & .25 & .57 & .23 & .79 & & & & & & & & & \\
\hline HM & .47 & .44 & .31 & .32 & .94 & & & & & & & & \\
\hline PV & .42 & .33 & .34 & .26 & .42 & .94 & & & & & & & \\
\hline HT & .43 & .29 & .55 & .26 & .48 & .46 & .81 & & & & & & \\
\hline SP & .04 & -.08 & .15 & -.06 & .08 & .08 & .16 & .72 & & & & & \\
\hline BI & .50 & .43 & .43 & .29 & .44 & .35 & .61 & .17 & .91 & & & & \\
\hline UB & .23 & .18 & .39 & .24 & .17 & .23 & .41 & .10 & .44 & $\mathrm{~N} / \mathrm{A}^{\mathrm{n}}$ & & & \\
\hline Age & -.01 & -.04 & .13 & -.03 & -.01 & .08 & .09 & .08 & .08 & .20 & N/A & & \\
\hline Gender & -.02 & -.04 & .05 & 0 & -.08 & .05 & 0 & .05 & -.03 & 0 & .11 & N/A & \\
\hline $\mathrm{CD}$ & -.08 & -.10 & .02 & -.08 & -.06 & -.02 & .03 & .24 & .01 & .13 & .18 & .09 & N/A \\
\hline
\end{tabular}

${ }^{\mathrm{a} O f f-d i a g o n a l ~ e l e m e n t s ~ a r e ~ c o r r e l a t i o n s . ~}$

${ }^{b}$ Diagonal elements are square roots of average variance extracted.

${ }^{\mathrm{c}} \mathrm{PE}$ : performance expectancy.

${ }^{\mathrm{d}} \mathrm{EE}$ : effort expectancy.

${ }^{\mathrm{e}} \mathrm{SI}$ : social influence.

${ }^{\mathrm{f}} \mathrm{FC}$ : facilitating conditions.

${ }^{\mathrm{g}} \mathrm{HM}$ : hedonic motivation.

${ }^{\mathrm{h}} \mathrm{PV}$ : price value.

${ }^{\mathrm{i}} \mathrm{HT}$ : habit.

${ }^{\mathrm{j}} \mathrm{SP}$ : self-perception.

${ }^{\mathrm{k}} \mathrm{BI}$ : behavioral intention.

${ }^{1}$ UB: use behavior.

${ }^{\mathrm{m}} \mathrm{CD}$ : chronic disability.

${ }^{\mathrm{n}} \mathrm{N} / \mathrm{A}$ : not applicable, because they are not reflective constructs.

Use, which was modelled using four formative indicators, is evaluated by specific quality criteria related to formative indicators. As seen in Table 5, the variance inflation factors are all below 5, suggesting that multi-collinearity is not an issue
[64]. In addition, the indicators comply with the criterion of being statistically significant or, if not significant, its outer loading must be higher than .50 [64]. 
Table 5. Formative indicators' quality criteria.

\begin{tabular}{llllll}
\hline Indicators & VIF $^{\mathrm{a}}$ & Weights & $t$ (weights) & Outer loadings & $t$ (loadings) \\
\hline $\mathrm{UB}^{\mathrm{b}}$ & 2.609 & .861 & $4.70^{\mathrm{c}}$ & .949 & $21.08^{\mathrm{c}}$ \\
$\mathrm{UB} 2$ & 1.707 & .354 & $2.27^{\mathrm{d}}$ & .746 & $8.41^{\mathrm{c}}$ \\
$\mathrm{UB} 3$ & 3.237 & .127 & 0.57 & .741 & $8.46^{\mathrm{c}}$ \\
UB4 & 2.472 & -.329 & 1.66 & .543 & $4.50^{\mathrm{c}}$ \\
\hline
\end{tabular}

${ }^{\mathrm{a}}$ VIF: variance inflation factor.

${ }^{\mathrm{b}} \mathrm{UB}$ : use behavior.

${ }^{\mathrm{c}} P<.01$.

$\mathrm{d}_{P<.05 \text {. }}$

In sum, all assessments are satisfactory. This means that the constructs can be used to test the conceptual model.

\section{Structural Model}

The structural model path significance levels were estimated using a bootstrap with 5000 iterations of resampling to obtain the highest possible consistency in the results. The $R^{2}$ was used to evaluate the structural model. Overall, the model explains $49.7 \%$ and $26.8 \%$ of the variance in behavioral intention and use behavior, respectively (see Figure 5).
Table 6 presents a summary of all the hypotheses tested and their support (or not) based on statistical tests. As Table 6 shows, the predictors of behavioral intention are performance expectancy (beta $=.200 ; t=3.619$ ), effort expectancy (beta $=.185$; $t=2.907$ ), habit (beta $=.388 ; t=7.320$ ), and self-perception (beta $=.098 ; t=2.285)$. The predictors of technology use behavior are habit (beta $=.206 ; t=2.752$ ) and behavioral intention (beta $=.258$; $t=4.036)$. Age also has a positive and significant effect on use behavior. This finding suggests that older individuals use EHR portal technologies more than do younger individuals. 
Figure 5. Structural model results. Notes: 1 . Moderated by age or gender; 2 . Moderated by age; 3 . Moderated by chronic disability on use; $* P<.01$; $* * P<.05$; ns: nonsignificant.

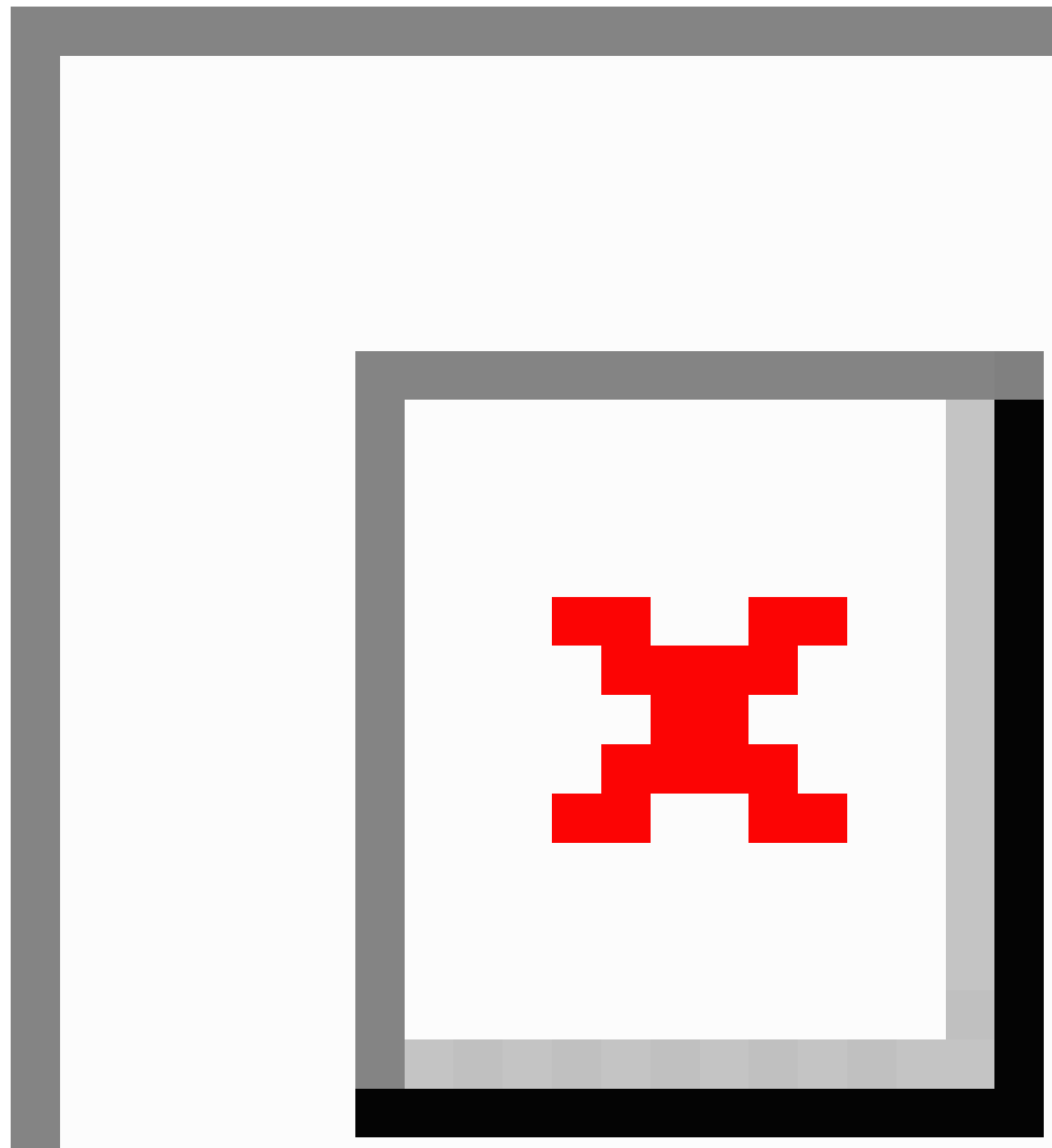

We also tested the mediating role of behavioral intention between the independent variables and use behavior (see Table 7). To test if behavior intention mediated the independent variables on use behavior, we followed the Preacher and Hayes [64] approach. Initially, we check if only direct effects—without mediator (ie, behavior intention)_are statistically significant in explaining use behavior. Based on this (Step 1) we concluded that habit, facilitating conditions, and social influence are statistically significant, meaning that any of these factors might mediate behavior intention. Then in Step 2, we include the mediator variable (ie, behavior intention) in order to test if indirect effect of habit, facilitating conditions, or social influence are significant on use behavior. Only the indirect effect of habit is statistically significant $(P<.01 ; t=3.472)$. Because of this fact, we compute the variance accounted for (VAF). The VAF is .38, meaning that behavior intention is a partial mediator of habit on use behavior [64]. Another important finding from this analysis is that in future studies it may be worth including a new relationship between social influence and use behavior, supported by a good literature background. This relationship is not foreseen in the UTAUT2 model. 
Table 6. Summary of findings regarding hypotheses.

\begin{tabular}{|c|c|c|c|c|c|}
\hline Dependent variables & Independent variables & Hypotheses $(\mathrm{H})$ & Beta & $t$ & $R^{2}$ \\
\hline \multirow[t]{16}{*}{ Behavioral intention } & & & & & $49.7 \%$ \\
\hline & $\mathrm{PE}^{\mathrm{a}}$ & H1 (supported) & .200 & $3.619^{1}$ & \\
\hline & $\mathrm{EE}^{\mathrm{b}}$ & H2 (supported) & .185 & $2.907^{1}$ & \\
\hline & $\mathrm{SI}^{\mathrm{c}}$ & H3 (not supported) & .081 & 1.544 & \\
\hline & $\mathrm{FC}^{\mathrm{d}}$ & H4 (a) (not supported) & .005 & 0.112 & \\
\hline & $\mathrm{HM}^{\mathrm{e}}$ & H5 (not supported) & .038 & 0.678 & \\
\hline & $P V^{f}$ & $\mathrm{~N} / \mathrm{A}^{\mathrm{g}}$ & -.010 & 0.203 & \\
\hline & PV $x$ age & H6 (not supported) & .026 & 0.563 & \\
\hline & $\mathrm{HT}^{\mathrm{h}}$ & N/A & .388 & $7.320^{1}$ & \\
\hline & HT $x$ age & H7 (a1) (not supported) & .033 & 0.584 & \\
\hline & HT $x$ gender & H7 (a2) (not supported) & .010 & 0.183 & \\
\hline & $S P^{i}$ & H8 (supported) & .098 & $2.285^{\mathrm{m}}$ & \\
\hline & Age & N/A & .065 & 1.408 & \\
\hline & Gender & N/A & .052 & 0.454 & \\
\hline & Gender $x$ age & N/A & -.087 & 0.078 & \\
\hline & $\mathrm{CD}^{\mathrm{j}}$ & N/A & -.002 & 0.049 & \\
\hline \multirow[t]{11}{*}{ Use behavior } & & & & & $26.8 \%$ \\
\hline & $\mathrm{FC}$ & & .090 & 1.755 & \\
\hline & $\mathrm{FC} \times \mathrm{CD}$ & H4 (b) (not supported) & .076 & 0.391 & \\
\hline & HT & N/A & .206 & $2.752^{1}$ & \\
\hline & HT $x$ age & H7 (b1) (not supported) & .060 & 0.621 & \\
\hline & HT $x$ gender & H7 (b2) (not supported) & .066 & 0.704 & \\
\hline & $\mathrm{BI}^{\mathrm{k}}$ & H9 (supported) & .258 & $4.036^{1}$ & \\
\hline & Age & N/A & .170 & $2.387^{\mathrm{m}}$ & \\
\hline & Gender & N/A & -.013 & 0.092 & \\
\hline & Gender $x$ age & N/A & .005 & 0.031 & \\
\hline & $\mathrm{CD}$ & N/A & -.081 & 0.476 & \\
\hline
\end{tabular}

${ }^{\mathrm{a}} \mathrm{PE}$ : performance expectancy.

${ }^{b}$ EE: effort expectancy.

${ }^{\mathrm{c}}$ SI: social influence.

${ }^{\mathrm{d}} \mathrm{FC}$ : facilitating conditions.

${ }^{\mathrm{e}} \mathrm{HM}$ : hedonic motivation.

${ }^{f} \mathrm{PV}$ : price value.

${ }^{\mathrm{N}} \mathrm{N} / \mathrm{A}$ : not applicable.

${ }^{\mathrm{h}} \mathrm{HT}$ : habit.

${ }^{\mathrm{i}} \mathrm{SP}$ : self-perception.

${ }^{\mathrm{j}} \mathrm{CD}$ : chronic disability.

${ }^{\mathrm{k}} \mathrm{BI}$ : behavioral intention.

${ }^{1} P<.01$.

$\mathrm{m}_{P<.05 \text {. }}$ 
Table 7. Mediating role of behavior intention on independent variables.

\begin{tabular}{|c|c|c|c|c|c|c|}
\hline \multirow{2}{*}{$\begin{array}{l}\text { Step } 1 \\
\text { Paths }\end{array}$} & \multirow[b]{2}{*}{ Beta } & \multirow[b]{2}{*}{$t$} & \multirow{2}{*}{$\begin{array}{l}\text { Step } 2 \\
\text { Paths }\end{array}$} & \multirow[b]{2}{*}{ Beta } & \multirow[b]{2}{*}{$t$} & \multirow[t]{2}{*}{$\mathrm{VAF}^{\mathrm{i}}$} \\
\hline & & & & & & \\
\hline & & & $\mathrm{PE}^{\mathrm{b}} \rightarrow \mathrm{BI}^{\mathrm{c}}$ & .200 & $3.673^{1}$ & \\
\hline & & & $\mathrm{EE}^{\mathrm{d}} \rightarrow \mathrm{BI}$ & .188 & $2.844^{1}$ & \\
\hline & & & $\mathrm{SI}^{\mathrm{e}} \rightarrow \mathrm{BI}$ & .082 & 1.616 & \\
\hline & & & $\mathrm{FC}^{\mathrm{f}} \rightarrow \mathrm{BI}$ & .007 & 0.161 & \\
\hline & & & $\mathrm{HM}^{\mathrm{g}} \rightarrow \mathrm{BI}$ & .036 & 0.659 & \\
\hline & & & $\mathrm{PV}^{\mathrm{h}} \rightarrow \mathrm{BI}$ & -.007 & 0.131 & \\
\hline & & & $\mathrm{HT}^{\mathrm{i}} \rightarrow \mathrm{BI}$ & .392 & $7.313^{1}$ & \\
\hline & & & $\mathrm{SP}^{\mathrm{j}} \rightarrow \mathrm{BI}$ & .105 & $2.521^{\mathrm{m}}$ & \\
\hline $\mathrm{PE} \rightarrow \mathrm{UB}^{\mathrm{k}}$ & .075 & 1.281 & $\mathrm{PE} \rightarrow \mathrm{UB}$ & .067 & 1.125 & \\
\hline $\mathrm{EE} \rightarrow \mathrm{UB}$ & -.023 & 0.481 & $\mathrm{EE} \rightarrow \mathrm{UB}$ & -.026 & 0.451 & \\
\hline $\mathrm{SI} \rightarrow \mathrm{UB}$ & .223 & $3.733^{1}$ & $\mathrm{SI} \rightarrow \mathrm{UB}$ & .228 & $3.389^{1}$ & \\
\hline $\mathrm{FC} \rightarrow \mathrm{UB}$ & .124 & $2.609^{1}$ & $\mathrm{FC} \rightarrow \mathrm{UB}$ & .132 & $2.578^{\mathrm{m}}$ & \\
\hline $\mathrm{HM} \rightarrow \mathrm{UB}$ & -.107 & 1.617 & $\mathrm{HM} \rightarrow \mathrm{UB}$ & -.112 & 1.629 & \\
\hline $\mathrm{PV} \rightarrow \mathrm{UB}$ & .012 & 0.192 & $\mathrm{PV} \rightarrow \mathrm{UB}$ & .019 & 0.312 & \\
\hline $\mathrm{HT} \rightarrow \mathrm{UB}$ & .278 & $3.733^{1}$ & $\mathrm{HT} \rightarrow \mathrm{UB}$ & .276 & $3.801^{1}$ & \\
\hline \multirow[t]{5}{*}{$\mathrm{SP} \rightarrow \mathrm{UB}$} & .065 & 1.122 & $\mathrm{SP} \rightarrow \mathrm{UB}$ & .050 & 0.869 & \\
\hline & & & $\mathrm{BI} \rightarrow \mathrm{UB}$ & .271 & $3.746^{1}$ & \\
\hline & & & $(\mathrm{FC} \rightarrow \mathrm{BI}) \times(\mathrm{BI} \rightarrow \mathrm{UB})$ & .003 & 0.256 & \\
\hline & & & $(\mathrm{SI} \rightarrow \mathrm{BI}) \times(\mathrm{BI} \rightarrow \mathrm{UB})$ & .021 & 1.390 & \\
\hline & & & $(\mathrm{HT} \rightarrow \mathrm{BI}) \times(\mathrm{BI} \rightarrow \mathrm{UB})$ & .106 & $3.472^{1}$ & .38 \\
\hline
\end{tabular}

${ }^{a}$ VAF: variance accounted for.

${ }^{\mathrm{b}} \mathrm{PE}$ : performance expectancy.

${ }^{\mathrm{c}} \mathrm{BI}$ : behavioral intention.

${ }^{\mathrm{d}}$ EE: effort expectancy.

${ }^{\mathrm{e}} \mathrm{SI}$ : social influence.

${ }^{\mathrm{f}} \mathrm{FC}$ : facilitating conditions.

${ }^{\mathrm{g}} \mathrm{HM}$ : hedonic motivation.

${ }^{\mathrm{h}} \mathrm{PV}$ : price value.

${ }^{\mathrm{i}} \mathrm{HT}$ : habit.

${ }^{\mathrm{j}} \mathrm{SP}$ : self-perception.

${ }^{\mathrm{k}} \mathrm{UB}$ : use behavior.

${ }^{1} P<.01$.

$\mathrm{m}_{P<.05}$.

\section{Discussion}

\section{Principal Findings}

The results suggest that using our research model in a health-related area-EHR portal acceptance by health care consumers-yields good results, explaining $49.7 \%$ of the variance on behavioral intention and $26.8 \%$ of the variance in technology use [2]. The most important contributors with significant impact on behavioral intention are performance expectancy, effort expectancy, habit, and self-perception. The predictors of use behavior are habit and behavioral intention. The inclusion of a specific construct-self-perception-related to the health care consumer area had a significant impact on understanding the adoption of EHR portals, revealing the usefulness of integrating it into our research model. Age also had a positive and significant effect on technology use. This finding suggests that older individuals use EHR portal technologies more than do younger individuals, a belief that is found in the literature. There, it is mentioned that as age 
increases, the need for health care services also increases, and that this is reflected in more frequent access to health care services [8,69]. Our results were not able to support the finding that patients with chronic illness or disability are more likely to use EHR portals if they have the resources and support available. Our study had a lower proportion of people who mentioned having a chronic disability or illness compared with other studies $[17,44]$. This fact, together with the fact that our sample was also younger than those from other studies $[17,44]$ and previous findings that older people usually require more support in using technologies [17,21,44], may explain why chronic disability did not achieve statistical significance as a moderator.

\section{Theoretical Implications}

Concerning our results, some of our hypotheses were supported and others not; both $\mathrm{H} 1$ and $\mathrm{H} 2$ were supported. In studies that have addressed similar problems, including those studying patient portals [19,30,31], both performance and effort expectancy, originally from TAM [36], also had a significant positive impact. In our study, social influence did not show a significant effect on behavioral intention, thereby not supporting H3. Although the literature mentions the potential impact of social influence on the adoption of eHealth technologies [20,52], another recent study using UTAUT2 in health and fitness apps found no significant impact of social influence on behavioral intention [40], which is aligned with our study results. The rejection of the facilitating conditions hypothesis, H4 (a), suggests that the subjects in our sample consider that the resources or knowledge to use EHR portals are not an issue. This can be explained by the facility of having access to a computer and the Internet $[4,12]$ and agrees with recent literature findings in eHealth [40].

Our results were also not able to confirm that patients with chronic illness or disability are more likely to use EHR portals if they have the resources and support available, as stated in $\mathrm{H} 4$ (b). This stands at odds with findings reported in the literature $[17,44]$. Earlier studies that addressed the concept behind H4 (b) included older people and those with a higher proportion of chronic disease or disability in the sample $[17,44]$. This may account for the difference in the results between our study and those reported in the literature. Future studies could address the degree or type of chronic disability.

Hedonic motivation also has no significant impact on behavioral intention (H5). Hedonic motivation is defined as intrinsic motivation (eg, enjoyment) for using EHR portals. Patients seem not to perceive the use of EHR portals as an enjoyment. This is probably because much of the use of portals is driven by the presence of a disease or a health problem, and the need for the portal is associated with that unfortunate fact-something that does not promote enjoyment $[53,70]$. Hedonic motivation had a positive impact on behavior intention in an eHealth study about health and fitness apps that promote balanced lifestyles [40]. These apps potentially have a greater impact on a person's hedonic motivation than the motives leading patients to use EHR portals. H6 was not verified. In Europe, access to the majority of eHealth services is free of charge [1,9], so the value that is given to the patients is to enable them to perform certain tasks more effectively online. Unfortunately, that fact is not being perceived by the patients.

The impact of habit in behavioral intention and use behavior was not moderated by age or gender; H7 (a1), H7 (a2), H7 (b1), and H7 (b2) were therefore not supported. However, the construct habit has a significant impact on both behavioral intention and use behavior, in line with findings from literature that mention habit as a predictor of behavioral intention and use behavior $[18,40]$. Self-perception, a construct related to health care, has a significant impact on behavioral intention, supporting H8. People who have a greater perception that they have health problems are more likely to use EHR portals. Our study's findings are in line with other studies in this regard [31,47]. H9-behavioral intention will positively influence use behavior-was also supported. Literature suggests that using specific eHealth platforms is preceded by the intention to use them [18,22,30,31,35,45].

Overall, we were able to demonstrate that habit, a construct specific to consumer technology acceptance, and self-perception, which is related to the area of knowledge we are testing, are both very important in understanding the acceptance of EHR portals. Specific tailor-made models that incorporate specific changes related to the study's topic may be an effective option for studying complex areas of knowledge, such as IT health care.

\section{Managerial Implications}

The findings of this study have valuable managerial implications for the conceptualization, design, and implementation of an EHR portal. We found that performance expectancy and effort expectancy have a significant impact on the adoption of EHR portals. Earlier studies using TAM identified these constructs as being relevant for the adoption of patient portals [30,41]. One of these studies adopted a qualitative TAM approach to evaluate patient portals [41], and the opinion of health care consumers in that study was that the design of these platforms should be simple and easy to use [41]. It is very important when designing or redeploying an EHR portal to make it easy and simple to use, and we therefore suggest that a pilot application of the platform be tested by the potential users so that improvements can be made during the development stage to increase the platform's acceptance [71,72]. Our results suggest that there is a significant impact of health care consumers' habit on EHR portal use. In addition to the direct and automatic effect of habit on technology use, habit also operates as a stored intention path to influence behavior [18]. This demands greater marketing communication effort to strengthen both the stored intention and its link to behavior [18]. Promotional strategies should therefore be implemented not only on the Internet, but also in the health care institutions that the patient usually goes to [56]. Because habit has been defined as the extent to which people tend to perform behaviors automatically because of learning [18], it is critical that EHR portals have client support services to help users with the platform. Another important finding is that the construct that is specific to health care-self-perception-also has a significant impact on the intention to use EHR portals. Self-perception relates to the fact that the perceived, rather than the real, severity of the health 
complaint is the propelling force behind the action [45]. Health care interventions that make the patient more aware of her/his health condition(s) may also promote the use of the EHR portal. Having a population that is better educated and more aware about health status could lead to a greater adoption of eHealth services, especially EHR portals. Overall, the managerial implications mentioned here are important not only for increasing the adoption of EHR portals, but also for increasing the frequency of usage of current users, who in most cases are not frequent users (see Figure 4). Figure 6 summarizes the managerial implications.

Figure 6. Managerial implications. EHR: electronic health record.

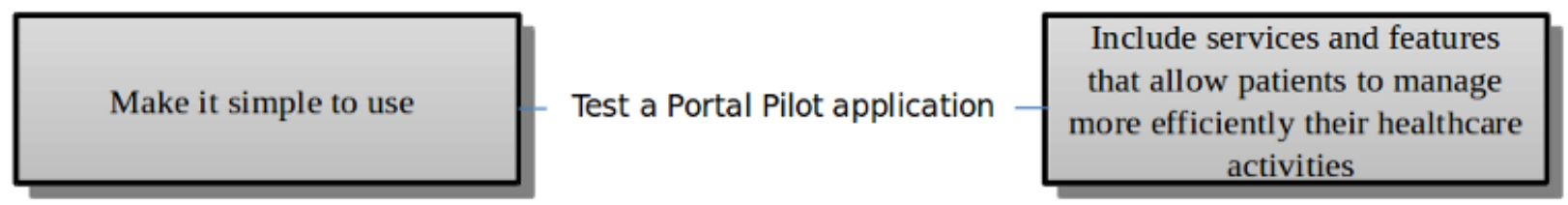

EHR Portals Adoption \& Use

Include educational health materials in the Portal
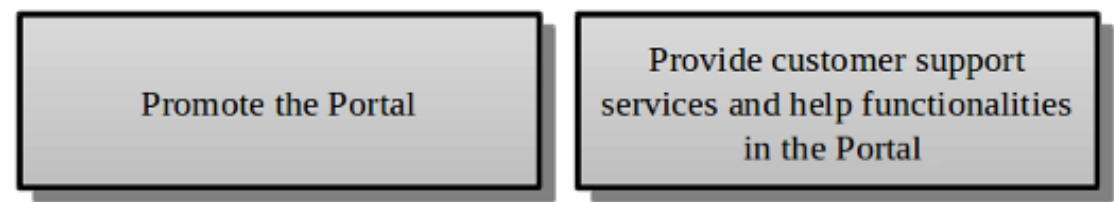

\section{Limitations and Future Research}

We acknowledge that this research is limited by the geographic location, as it pertains to only one country and to only a sample of educational institutions. According to the literature, the technology that we are studying - EHR portals - is being used by less than $7 \%$ of the total number of health care consumers or patients $[5,7,56]$. The literature also mentions that users and early adopters of these types of platforms are younger than the population average and have significantly higher education $[19,43,59]$. Using a sampling strategy suitable to low-prevalence populations $[57,58]$, we focused our sampling on educational institutions, where our target population is more concentrated [57]. It is also common to find studies that evaluate eHealth portals, addressing the users of a particular portal [16,19,30]. This is also a good strategy to target rare populations, but is also potentially biased as it reflects the opinions of only the users of a certain portal $[19,57]$. Another important fact that we acknowledge as a limitation in this study is that we were not able to collect the answers at more than one point in time. As a result, we could not use experience as a moderator in this study. Difficulties targeting the user population and the sensitivity of the topic related to EHRs [2] contributed to this limitation. The impact of chronic disability/illness as a positive moderator of facilitating conditions to explain technology use — pointed out as a possibility in the literature [17,44]—was not detected in our study. Nevertheless, only a small proportion of our sample (14.4\%) mentioned having a chronic disability or illness and we did not collect information about its type or degree. Future studies might investigate this issue in greater depth.
Regarding the model tested, the inclusion of a health-related construct with significant positive impact demonstrates that it is relevant and that its inclusion is warranted. It also reveals the value of adding specific constructs related to the area in which the technology is used to existing frameworks. For future studies, it may also be advantageous to include other constructs (eg, confidentiality) that are not specific to health care but which, according to the literature, may be influential in eHealth adoption [2,19], or new relationships such as the one between social influence and use behavior. Some constructs from UTAUT2, notably hedonic motivation, do not seem to be relevant for EHR portal adoption and, in fact, self-perception seems to be a better motivational predictor. Future studies may therefore exclude this construct in order to avoid adding redundant complexity to the model. Another interesting future contribution is to evaluate mediated moderation in the research model.

\section{Conclusions}

EHR portal adoption is a new and growing field of study that is an important topic in government-level discussions in the European Union and the United States. In our study, we used a new model in which we identified key additional constructs and relationships based on the literature review that are specific to IT health care adoption and integrated them into UTAUT2. The research model was tested and was found to explain $49.7 \%$ of the variance in behavioral intention and $26.8 \%$ of the variance in EHR portal technology use. Of all the constructs tested, performance expectancy, effort expectancy, self-perception, and habit had the most significant effects on behavioral intention. Habit and behavioral intention had a significant effect on technology use. Two specific constructs-habit (consumer related) and self-perception (health care)—were very significant 
in explaining the adoption of EHR portals, showing how important it is to use specific adoption models that include constructs specific to the area. The impact of chronic disability as a moderator of facilitating conditions to explain use behavior was not supported in our study. Not only is the adoption of EHR portals still low, but most current users of these platforms use them only infrequently. We used the results obtained in this study to provide managerial insights that may increase the adoption and usage of EHR portals.

\section{Conflicts of Interest}

None declared.

\section{Multimedia Appendix 1}

Questionnaire items.

[PDF File (Adobe PDF File), 172KB-Multimedia Appendix 1]

\section{Multimedia Appendix 2}

Partial least squares (PLS) loadings and cross-loadings.

[PDF File (Adobe PDF File), 38KB-Multimedia Appendix 2]

\section{References}

1. Andreassen HK, Bujnowska-Fedak MM, Chronaki CE, Dumitru RC, Pudule I, Santana S, et al. European citizens' use of E-health services: A study of seven countries. BMC Public Health 2007;7:53 [FREE Full text] [doi: 10.1186/1471-2458-7-53] [Medline: 17425798$]$

2. Angst CM, Agarwal R. Adoption of electronic health records in the presence of privacy concerns: The elaboration likelihood model and individual persuasion. MIS Q 2009;33(2):339-370.

3. Weingart SN, Rind D, Tofias Z, Sands DZ. Who uses the patient internet portal? The PatientSite experience. J Am Med Inform Assoc 2006;13(1):91-95 [FREE Full text] [doi: 10.1197/jamia.M1833] [Medline: 16221943]

4. Tavares J, Oliveira T. E-health Web based technologies patient adoption. Rev Saude Publica 2014;48 (n.esp):25.

5. Ancker JS, Barrón Y, Rockoff ML, Hauser D, Pichardo M, Szerencsy A, et al. Use of an electronic patient portal among disadvantaged populations. J Gen Intern Med 2011 Oct;26(10):1117-1123 [FREE Full text] [doi: 10.1007/s11606-011-1749-y] [Medline: 21647748]

6. Knaup P, Schöpe L. Using data from ambient assisted living and smart homes in electronic health records. Methods Inf Med 2014;53(3):149-151. [doi: 10.3414/ME14-10-0003] [Medline: 24828122]

7. HealthCare IT News. 2013 Jan 02. Patient portals: Providers choose path of least resistance URL: http://www. healthcareitnews.com/press-release/patient-portals-providers-choose-path-least-resistance [accessed 2016-02-25] [WebCite Cache ID 6fZ0TKdvl]

8. Alpay LL, Henkemans OB, Otten W, Rövekamp TA, Dumay AC. E-health applications and services for patient empowerment: Directions for best practices in The Netherlands. Telemed J E Health 2010 Sep;16(7):787-791. [doi: 10.1089/tmj.2009.0156] [Medline: 20815745]

9. Commission of the European Communities. e-Health - Making Healthcare Better for European Citizens: An Action Plan for a European e-Health Area. Brussels, Belgium: European Commission; 2004 Apr 30. URL: http://eur-lex.europa.eu/ LexUriServ/LexUriServ.do?uri=COM:2004:0356:FIN:EN:PDF [accessed 2015-08-23] [WebCite Cache ID 6b0PAfTzA]

10. McKee M, Karanikolos M, Belcher P, Stuckler D. Austerity: A failed experiment on the people of Europe. Clin Med 2012 Aug;12(4):346-350. [Medline: 22930881]

11. Metaxiotis K, Ptochos D, Psarras J. E-health in the new millennium: A research and practice agenda. Int J Electron Healthc 2004;1(2):165-175. [doi: 10.1504/IJEH.2004.005865] [Medline: 18048218 ]

12. Rodrigues DF, Lopes JC, Tavares JF. Manifold-Marketing: A new marketing archetype for the information age, applied to the adoption of oral contraceptives and other drugs by end-users. In: Proceedings of the 3rd Annual Conference of International Network of Business \& Management Journals (INBAM). 2013 Presented at: The 3rd Annual Conference of International Network of Business \& Management Journals (INBAM); June 17-19, 2013; Lisbon, Portugal.

13. epSOS. 2014. About epSOS URL: http://www.epsos.eu/home/about-epsos.html [accessed 2015-08-21] [WebCite Cache ID 6 ax7uyDBE]

14. HealthIT.gov. 2014. Step 5: Achieve meaningful use Stage 2 URL: http://www.healthit.gov/providers-professionals/ step-5-achieve-meaningful-use-stage-2 [accessed 2015-08-21] [WebCite Cache ID 6ax7dD0hG]

15. Irwin K. Software Advice. Patient portal preferences: IndustryView 2014 URL: http://www.softwareadvice.com/medical/ industryview/patient-portals-2014/ [accessed 2015-08-23] [WebCite Cache ID 6b0PGRaLL]

16. Lemire M, Sicotte C, Paré G. Internet use and the logics of personal empowerment in health. Health Policy 2008 Oct;88(1):130-140. [doi: 10.1016/j.healthpol.2008.03.006] [Medline: 18436330] 
17. Millard RW, Fintak PA. Use of the Internet by patients with chronic illness. Dis Manag Health Outcomes 2002;10(3):187-194.

18. Venkatesh V, Thong JYL, Xu X. Consumer acceptance and use of information technology: Extending the unified theory of acceptance and use of technology. MIS Q 2012;36(1):425-478.

19. Or CK, Karsh B. A systematic review of patient acceptance of consumer health information technology. J Am Med Inform Assoc 2009 Aug;16(4):550-560 [FREE Full text] [doi: 10.1197/jamia.M2888] [Medline: 19390112]

20. Thackeray R, Crookston BT, West JH. Correlates of health-related social media use among adults. J Med Internet Res 2013;15(1):e21 [FREE Full text] [doi: 10.2196/jmir.2297] [Medline: 23367505]

21. Peek ST, Wouters EJ, van Hoof J, Luijkx KG, Boeije HR, Vrijhoef HJ. Factors influencing acceptance of technology for aging in place: A systematic review. Int J Med Inform 2014 Apr;83(4):235-248 [FREE Full text] [doi: 10.1016/j.ijmedinf.2014.01.004] [Medline: 24529817]

22. Lai JY, Wang JT. Switching attitudes of Taiwanese middle-aged and elderly patients toward cloud healthcare services: An exploratory study. Technol Forecast Soc Change 2015 Mar;92:155-167. [doi: 10.1016/j.techfore.2014.06.004]

23. Dünnebeil S, Sunyaev A, Blohm I, Leimeister JM, Krcmar H. Determinants of physicians' technology acceptance for e-health in ambulatory care. Int J Med Inform 2012 Nov;81(11):746-760. [doi: 10.1016/j.ijmedinf.2012.02.002] [Medline: 22397989]

24. Ketikidis P, Dimitrovski T, Lazuras L, Bath PA. Acceptance of health information technology in health professionals: An application of the revised technology acceptance model. Health Informatics J 2012 Jun;18(2):124-134. [doi:

10.1177/1460458211435425] [Medline: 22733680]

25. Chang I, Hwang H, Hung W, Li Y. Physicians' acceptance of pharmacokinetics-based clinical decision support systems. Expert Syst Appl 2007 Aug;33(2):296-303. [doi: 10.1016/j.eswa.2006.05.001]

26. Yi MY, Jackson JD, Park JS, Probst JC. Understanding information technology acceptance by individual professionals: Toward an integrative view. Inf Manage 2006 Apr;43(3):350-363. [doi: 10.1016/j.im.2005.08.006]

27. Maillet E, Mathieu L, Sicotte C. Modeling factors explaining the acceptance, actual use and satisfaction of nurses using an Electronic Patient Record in acute care settings: An extension of the UTAUT. Int J Med Inform 2015 Jan;84(1):36-47. [doi: 10.1016/j.ijmedinf.2014.09.004] [Medline: 25288192]

28. Vanneste D, Vermeulen B, Declercq A. Healthcare professionals' acceptance of BelRAI, a web-based system enabling person-centred recording and data sharing across care settings with interRAI instruments: A UTAUT analysis. BMC Med Inform Decis Mak 2013;13:129 [FREE Full text] [doi: 10.1186/1472-6947-13-129] [Medline: 24279650]

29. Vinko M, Brecelj S, Erzen I, Dinevski D. Acceptance and use of health information technology in Slovenian public health institutions: A national survey based on UTAUT model. Zdravniski Vestn 2013;82(4):234-242.

30. Wilson EV, Lankton NK. Modeling patients' acceptance of provider-delivered e-health. J Am Med Inform Assoc 2004;11(4):241-248 [FREE Full text] [doi: 10.1197/jamia.M1475] [Medline: 15064290]

31. Kim J, Park H. Development of a health information technology acceptance model using consumers' health behavior intention. J Med Internet Res 2012;14(5):e133 [FREE Full text] [doi: 10.2196/jmir.2143] [Medline: 23026508]

32. Ahadzadeh AS, Pahlevan SS, Ong FS, Khong KW. Integrating health belief model and technology acceptance model: An investigation of health-related Internet use. J Med Internet Res 2015;17(2):e45 [FREE Full text] [doi: 10.2196/jmir.3564] [Medline: 25700481]

33. Wong CK, Yeung DY, Ho HC, Tse KP, Lam CY. Chinese older adults' Internet use for health information. J Appl Gerontol 2014 Apr;33(3):316-335. [doi: 10.1177/0733464812463430] [Medline: 24717738]

34. Nasir S, Yurder Y. Consumers' and physicians' perceptions about high tech wearable health products. Procedia Soc Behav Sci 2015 Jul;195:1261-1267. [doi: 10.1016/j.sbspro.2015.06.279]

35. Venkatesh V, Morris MG, Davis GB, Davis FD. User acceptance of information technology: Toward a unified view. MIS Q 2003;27(3):157-178.

36. Davis FD. Perceived usefulness, perceived ease of use, and user acceptance of information technology. MIS Q 1989 Sep;13(3):319. [doi: 10.2307/249008]

37. Baptista G, Oliveira T. Understanding mobile banking: The unified theory of acceptance and use of technology combined with cultural moderators. Comput Human Behav 2015 Sep;50:418-430. [doi: 10.1016/j.chb.2015.04.024]

38. Pascual-Miguel FJ, Agudo-Peregrina AF, Chaparro-Peláez J. Influences of gender and product type on online purchasing. J Bus Res 2015 Jul;68(7):1550-1556. [doi: 10.1016/j.jbusres.2015.01.050]

39. Lian J. Critical factors for cloud based e-invoice service adoption in Taiwan: An empirical study. Int J Inf Manage 2015 Feb;35(1):98-109. [doi: 10.1016/j.ijinfomgt.2014.10.005]

40. Yuan S, Ma W, Kanthawala S, Peng W. Keep using my health apps: Discover users' perception of health and fitness apps with the UTAUT2 model. Telemed J E Health 2015 Sep;21(9):735-741. [doi: 10.1089/tmj.2014.0148] [Medline: 25919238]

41. Jung M, Loria K. Acceptance of Swedish e-health services. J Multidiscip Healthc 2010;3:55-63 [FREE Full text] [doi: 10.2147/JMDH.S9159] [Medline: 21289860]

42. Lemire M, Paré G, Sicotte C, Harvey C. Determinants of Internet use as a preferred source of information on personal health. Int J Med Inform 2008 Nov;77(11):723-734. [doi: 10.1016/j.ijmedinf.2008.03.002] [Medline: 18434246] 
43. Renahy E, Parizot I, Chauvin P. Health information seeking on the Internet: A double divide? Results from a representative survey in the Paris metropolitan area, France, 2005-2006. BMC Public Health 2008;8:69 [FREE Full text] [doi: 10.1186/1471-2458-8-69] [Medline: 18291024 ]

44. Fox S. E-Patients With a Disability or Chronic Disease. Washington, DC: Pew Internet \& American Life Project; 2007 Oct 08. URL: http://www.pewinternet.org/files/old-media/Files/Reports/2007/EPatients Chronic Conditions 2007.pdf.pdf [accessed 2015-08-23] [WebCite Cache ID 6b0Pp5ELp]

45. van de Kar A, Knottnerus A, Meertens R, Dubois V, Kok G. Why do patients consult the general practitioner? Determinants of their decision. Br J Gen Pract 1992 Aug;42(361):313-316 [FREE Full text] [Medline: 1457150]

46. Chan KM, Pang WS, Ee CH, Ding YY, Choo P. Self-perception of health among elderly community dwellers in Singapore. Ann Acad Med Singapore 1998 Jul;27(4):461-467. [Medline: 9791647]

47. Kaleta D, Polańska K, Dziankowska-Zaborszczyk E, Hanke W, Drygas W. Factors influencing self-perception of health status. Cent Eur J Public Health 2009 Sep;17(3):122-127. [Medline: 20020600]

48. Menec VH, Chipperfield JG, Perry RP. Self-perceptions of health: A prospective analysis of mortality, control, and health. J Gerontol B Psychol Sci Soc Sci 1999 Mar;54(2):P85-P93. [Medline: 10097770]

49. Martins C, Oliveira T, Popovič A. Understanding the Internet banking adoption: An unified theory of acceptance and use of technology and perceived risk application. Int J Inf Manage 2014;34(1):1-13.

50. Arsand E, Demiris G. User-centered methods for designing patient-centric self-help tools. Inform Health Soc Care 2008 Sep;33(3):158-169. [doi: 10.1080/17538150802457562] [Medline: 18850399]

51. Keselman A, Logan R, Smith CA, Leroy G, Zeng-Treitler Q. Developing informatics tools and strategies for consumer-centered health communication. J Am Med Inform Assoc 2008;15(4):473-483 [FREE Full text] [doi: 10.1197/jamia.M2744] [Medline: 18436895]

52. Fisher J, Clayton M. Who gives a tweet: Assessing patients' interest in the use of social media for health care. Worldviews Evid Based Nurs 2012 Apr;9(2):100-108. [doi: 10.1111/j.1741-6787.2012.00243.x] [Medline: 22432730]

53. Lee C, Gray SW, Lewis N. Internet use leads cancer patients to be active health care consumers. Patient Educ Couns 2010 Dec;81 Suppl:S63-S69 [FREE Full text] [doi: 10.1016/j.pec.2010.09.004] [Medline: 20889279]

54. Millard RW, Fintak PA. Use of the Internet by patients with chronic illness. Dis Manag Health Outcomes 2002;10(3):187-194. [doi: 10.2165/00115677-200210030-00006]

55. Brislin RW. Back-translation for cross-cultural research. J Cross Cult Psychol 1970 Sep 01;1(3):185-216. [doi: $10.1177 / 135910457000100301]$

56. Yasnoff WA, Shortliffe EH. Lessons learned from a health record bank start-up. Methods Inf Med 2014;53(2):66-72. [doi: 10.3414/ME13-02-0030] [Medline: 24477917]

57. Kalton G, Anderson DW. Sampling rare populations. J R Stat Soc Ser A 1986;149(1):65. [doi: 10.2307/2981886]

58. Picot SJF, Samonte J, Tierney JA, Connor J, Powel LL. Effective sampling of rare population elements: Black female caregivers and noncaregivers. Res Aging 2001 Nov 01;23(6):694-712. [doi: 10.1177/0164027501236004]

59. Roblin DW, Houston TK, Allison JJ, Joski PJ, Becker ER. Disparities in use of a personal health record in a managed care organization. J Am Med Inform Assoc 2009;16(5):683-689 [FREE Full text] [doi: 10.1197/jamia.M3169] [Medline: 19567790]

60. Henseler J, Ringle CM, Sinkovics RR. The use of partial least squares path modeling in international marketing. In: Sinkovics RR, Ghauri PN, editors. Advances in International Marketing: New Challenges to International Marketing (Volume 20). Bingley, UK: Emerald Group Publishing Limited; 2009:277-319.

61. Götz O, Liehr-Gobbers K, Krafft M. Evaluation of structural equation models using the partial least squares (PLS) approach. In: Vinzi VE, Chin WW, Henseler J, Wang H, editors. Handbook of Partial Least Squares: Concepts, Methods and Applications. Berlin, Germany: Springer Berlin Heidelberg; 2010:691-711.

62. Hair JF, Ringle CM, Sarstedt M. PLS-SEM: Indeed a silver bullet. J Mark Theory Pract 2011;19(2):139-151.

63. Ringle CM, Wende S, Will A. SmartPLS. 2005. URL: http://www.smartpls.de [accessed 2015-08-23] [WebCite Cache ID 6fJ4u0UbM]

64. Hair J, Hult GT, Ringle CM, Sarstedt M. A Primer on Partial Least Squares Structural Equation Modeling (PLS-SEM). Thousand Oaks, CA: SAGE Publications, Inc; 2014.

65. MacKenzie SB, Podsakoff PM, Podsakoff NP. Construct measurement and validation procedures in MIS and behavioral research: Integrating new and existing techniques. MIS Q 2011;35(2):293-334.

66. Churchill GA. A paradigm for developing better measures of marketing constructs. J Mark Res 1979;16(1):64-73.

67. Fornell C, Larcker DF. Structural equation models with unobservable variables and measurement error: Algebra and statistics. J Mark Res 1981 Aug;18(3):382. [doi: 10.2307/3150980]

68. Chin WW. The partial least squares approach for structural equation modeling. In: Marcoulides GA, editor. Modern Methods for Business Research. Mahwah, NJ: Lawrence Erlbaum Associates; 1998:295-336.

69. Hunt SM, McKenna SP, McEwen J, Backett EM, Williams J, Papp E. A quantitative approach to perceived health status: A validation study. J Epidemiol Community Health 1980 Dec;34(4):281-286 [FREE Full text] [Medline: 7241028]

70. Osborn CY, Mayberry LS, Wallston KA, Johnson KB, Elasy TA. Understanding patient portal use: Implications for medication management. J Med Internet Res 2013;15(7):e133 [FREE Full text] [doi: 10.2196/jmir.2589] [Medline: 23823974] 
71. Kelders SM, Pots WT, Oskam MJ, Bohlmeijer ET, van Gemert-Pijnen JE. Development of a web-based intervention for the indicated prevention of depression. BMC Med Inform Decis Mak 2013;13:26 [FREE Full text] [doi: 10.1186/1472-6947-13-26] [Medline: 23425322]

72. Bjerkan J, Hedlund M, Helles $\varnothing$ R. Patients' contribution to the development of a web-based plan for integrated care - A participatory design study. Inform Health Soc Care 2015 Mar;40(2):167-184. [doi: 10.3109/17538157.2014.907803] [Medline: 24786524]

\section{Abbreviations}

AVE: average variance extracted

BI: behavioral intention

CD: chronic disability

CFIP: concern for information privacy

CMS: Centers for Medicare \& Medicaid Services

CR: composite reliability coefficient

EE: effort expectancy

EHR: electronic health record

ELM: elaboration likelihood model

epSOS: European Patients Smart Open Services

FC: facilitating conditions

H1: hypothesis 1

H2: hypothesis 2

H3: hypothesis 3

H4 (a): hypothesis 4 (a)

H4 (b): hypothesis 4 (b)

H5: hypothesis 5

H6: hypothesis 6

H7 (a1): hypothesis 7 (a1)

H7 (a2): hypothesis 7 (a2)

H7 (b1): hypothesis 7 (b1)

H7 (b2): hypothesis 7 (b2)

H8: hypothesis 8

H9: hypothesis 9

HBM: health belief model

HIT: health information technology

HM: hedonic motivation

HT: habit

ICT: information and communication technology

IM: integrated model

IMS: Information Management School

IS: information systems

IT: information technology

MM: motivational model

N/A: not applicable

ns: nonsignificant

PE: performance expectancy

PEOU: perceived ease of use

PLS: partial least squares

PU: perceived usefulness

PV: price value

SI: social influence

SP: self-perception

TAM: technology acceptance model

UB: use behavior

UTAUT: unified theory of acceptance and use of technology

UTAUT2: unified theory of acceptance and use of technology in a consumer context

VAF: variance accounted for

VIF: variance inflation factor 
Edited by G Eysenbach; submitted 25.08.15; peer-reviewed by S Pahlevan Sharif, A Ahadzadeh; comments to author 01.10.15; revised version received 15.11.15; accepted 04.01.16; published 02.03.16

Please cite as:

Tavares J, Oliveira T

Electronic Health Record Patient Portal Adoption by Health Care Consumers: An Acceptance Model and Survey

J Med Internet Res 2016;18(3):e49

URL: $\underline{\text { http://www.jmir.org/2016/3/e49/ }}$

doi: 10.2196/jmir.5069

PMID: 26935646

CJorge Tavares, Tiago Oliveira. Originally published in the Journal of Medical Internet Research (http://www.jmir.org), 02.03.2016. This is an open-access article distributed under the terms of the Creative Commons Attribution License (http://creativecommons.org/licenses/by/2.0/), which permits unrestricted use, distribution, and reproduction in any medium, provided the original work, first published in the Journal of Medical Internet Research, is properly cited. The complete bibliographic information, a link to the original publication on http://www.jmir.org/, as well as this copyright and license information must be included. 